\title{
Pengembangan Media Pembelajaran Terapi Masase Berbasis Aplikasi Articulate Storyline
}

\author{
Muhammad Fahmi Amiruddin*, Ari Wibowo Kurniawan \\ Universitas Negeri Malang, Jl. Semarang No. 5 Malang, Jawa Timur, Indonesia \\ *Penulis korespondensi, Surel: m.f.amiruddin.24@gmail.com
}

Paper received: 17-6-2021; revised: 1-7-2021; accepted: 8-7-2021

\begin{abstract}
This research and development aims to develop massage therapy learning media based on the articulate storyline application which can later be used in learning in the PJKR FIK UM department and can make it easier for students to understand massage therapy material. The method used is the Research and Development approach with a development research model with the steps (1) needs analysis, (2) doing product design (design), (3) product development (development), (4) implementation or (implementation), and (5) product evaluation (evaluation). The test results of the whole product involved 60 students of PJKR FIK UM. Based on the results of data analysis obtained from trials with aspects of ease, clarity, attractiveness, suitability, and usefulness, the average result is 95 percent in small group trials with 10 students as subjects and 90 percent in large group trials with 50 students as subjects. Based on the results of data analysis, it can be concluded that the product of developing massage therapy learning media based on the articulate storyline application can be said to be suitable for use as massage therapy learning media for students majoring in PJKR FIK UM.
\end{abstract}

Keywords: learning media; therapy massage; articulate storyline application

\begin{abstract}
Abstrak
Penelitian dan pengembangan ini bertujuan untuk mengembangkan media pembelajaran terapi masase berbasis aplikasi articulate storyline yang nantinya dapat digunakan dalam pembelajaran di jurusan PJKR FIK UM dan dapat mempermudah mahasiswa dalam memahami materi terapi masase. Metode yang digunakan yaitu pendekatan Research and Development dengan model penelitian pengembangan dengan langkah-langkah (1) Analisis kebutuhan (analysis), (2) melakukan desain produk (design), (3) pengembangan produk (development), (4) pelaksanaan atau (implementation), dan (5) evaluasi produk (evaluation). Hasil uji coba keseluruhan produk melibatkan 60 mahasiswa PJKR FIK UM. Berdasarkan hasil analisis data yang diperoleh dari uji coba dengan aspek kemudahan, kejelasan, kemenarikan, kesesuaian, dan kegunaan mendapatkan hasil rata-rata sebesar 95 persen pada uji coba kelompok kecil dengan jumlah subjek 10 mahasiswa dan 90 persen pada uji coba kelompok besar dengan jumlah subjek 50 mahasiswa. Berdasarkan hasil analisis data dapat disimpulkan bahwa produk pengembangan media pembelajaran terapi masase berbasis aplikasi articulate storyline dapat dikatakan layak digunakan sebagai media pembelajaran terapi masase untuk mahasiswa jurusan PJKR FIK UM.
\end{abstract}

Kata kunci: media pembelajaran; terapi masase; aplikasi articulate storyline

\section{Pendahuluan}

Kemajuan dari Ilmu Pengetahuan dan Teknologi (IPTEK) telah berpengaruh terhadap semua ruang lingkup kehidupan. Pekerjaan yang biasanya dilakukan dengan cara manual, sekarang dapat dilakukan dengan menggunakan mesin. Kemajuan teknologi dengan adanya era digital ini memungkinkan terjadinya otomatisasi hampir di semua bidang (Tjandrawinata \& Medica, 2016). Hal ini mengakibatkan manusia dituntut untuk berpikir lebih maju dalam berbagai hal, supaya nantinya tidak dianggap tertinggal. Ilmu Pengetahuan dan Teknologi (IPTEK) tentunya sangat berpengaruh terhadap dunia pendidikan dan proses pembelajaran. 
Untuk itu, seorang pendidik diharapkan mampu menyusun dan menerapkan strategi pembelajaran yang baik. Melalui kemajuan bidang ilmu pengetahuan dan teknologi tersebut, pendidik dapat menggunakan berbagai macam media dalam pembelajaran. Didalam proses belajar mengajar, media yang dipakai atau digunakan guru atau pendidik harus sesuai dengan tujuan pembelajaran yang sudah ditetapkan, sehingga nantinya mampu untuk merangsang dan juga menumbuhkan minat siswa atau peserta didik dalam proses belajar (Wena, 2013). Dengan demikian, bahan ajar atau sumber belajar yang digunakan harus disesuaikan dengan kebutuhan dan tujuan pembelajaran, sehingga nantinya akan mempermudah, memperlancar, dan mengefektifkan proses belajar mengajar, serta dapat membuat proses belajar mengajar akan menjadi lebih menarik. Peserta didik lebih tertarik terhadap segala sesuatu yang berbau teknologi mulai dari permainan, informasi, jasa, dan lain sebagainya (Nurpitasari, Aji, \& Kurniawan, 2018).

Proses pembelajaran atau belajar mengajar adalah suatu proses yang terdapat interaksi antara guru atau pendidik dengan murid atau peserta didik. Pembelajaran merupakan kegiatan belajar yang antara lain dilakukan oleh guru dalam mengkondisikan seseorang untuk belajar, proses interaksi antara guru dengan peserta didik baik interaksi secara langsung seperti kegiatan tatap muka maupun secara tidak langsung atau online, yaitu dengan menggunakan berbagai media pembelajaran yang menarik untuk peserta didik (Asmadawati, 2014). Guru atau pendidik merupakan sebuah komponen yang sangat penting dari tenaga kependidikan, yang memiliki tugas melaksanakan pembelajaran atau belajar mengajar (Wena, 2013). Guru atau pendidik menjalankan peran yang sangat penting dalam perubahan budaya melalui pengaturan persekolahan, khususnya dalam melaksanakan interaksi antara peserta didik dengan bahan ajar atau sumber belajar yang nantinya bertujuan mencapai prestasi yang diinginkan peserta didik. Jadi, dalam proses pembelajaran, pendidik dan peserta didik merupakan anggota yang penting dan tidak dapat dipisahkan, antara pendidik dan peserta didik harus terjalin interaksi yang baik dan bagus supaya tujuan belajar mengajar/pembelajaran dapat tercapai secara maksimal.

Pembelajaran pada umumnya dilaksanakan mulai dari tingkat SD (Sekolah Dasar), tingkat SMP (Sekolah Menengah Pertama), tingkat SMA (Sekolah Menengah Atas), sampai PT (Perguruan Tinggi) yang didalamnya terdapat kurikulum. Kurikulum adalah kumpulan standar kompetensi pelajaran atau bidang studi (Toenlioe, 2017). Misalnya standar kompetensi IPA, IPS, matematika, PJOK, dan bahasa. Sama halnya dengan kurikulum yang ada di perguruan tinggi yaitu sama seperti kumpulan matakuliah. Kurikulum yang terdapat di perguruan tinggi (PT) khususnya di program studi PJKR FIK UM terdapat matakuliah teori dan praktik. Matakuliah yang berupa praktik salah satunya adalah masase. Dengan adanya mata kuliah praktek masase, maka pendidik atau dosen akan mencari dan memilih metode yang sesuai. Selain dari pemilihan metode pembelajaran, pemilihan media pembelajaran juga berfungsi sebagai upaya dalam mencapai tujuan pembelajaran. Hal ini menjadi penting, karena tidak semua mahasiswa PJKR FIK UM mengenal tentang masase Terapi masase merupakan salah satu penanganan dalam cedera, adapun perawatan setelah cedera dapat dengan terapi latihan agar kondisi cedera pulih sempurna (Harsanti \& Graha, 2014). Masase dapat didefinisikan sebagai manipulasi sistematis jaringan lunak tubuh untuk mengurangi rasa sakit atau tujuan terapeutik lainnya. Masase adalah manipulasi sistematis dari jaringan lunak tubuh dengan tekanan ritmis dan membelai, mencegah, mengembangkan, memelihara, merehabilitasi, atau menambah fisik berfungsi atau menghilangkan rasa sakit (Bervoets, Luijsterburg, Alessie, 
Buijs, \& Verhagen, 2015). Masase merupakan manipulasi yang bertujuan untuk merilekskan otot otot yang tegang, melancarkan peredaran darah, dan limfe.

Media pembelajaran adalah segala sesuatu yang digunakan sebagai komunikasi atau untuk menyampaikan pesan, informasi / materi pembelajaran sehingga untuk merangsang perhatian, minat, pemikiran dan perasaan siswa kegiatan belajar untuk mencapai tujuan pembelajaran tertentu (Kurniawan, 2019). Menurut Mukhlis, Kurniawan, \& Kurniawan (2020) Pembelajaran menggunakan multimedia interaktif mampu membuat peserta didik lebih aktif untuk belajar dengan motivasi yang tinggi karena ketertarikannya pada media pembelajaran yang mampu menampilkan teks, gambar, video, suara dan animasi.

Manfaat media pembelajaran menurut (Dwijayani, 2019) ada dua, pertama, sebagai pedoman bagi guru untuk mencapai tujuan pembelajaran dan dapat menjelaskan materi pembelajaran dengan urutan yang sistematis dan penyajian yang menarik, kedua,dapat meningkatkan motivasi dan minat belajar peserta didik sehingga peserta didik dapat berfikir dan menganalisis materi yang diberikan oleh guru dengan baik dalam situasi pembelajaran yang menyenangkan.

Pada zaman sekarang ini tentunya pendidikan harus mengikuti perkembangan zaman dimana teknologi berkembang sangat pesat. Salah satunya adalah di bidang pendidikan. Zaman sekarang telah banyak media pembelajaran yang dapat guru gunakan, seperti Articulate storyline aplikasi yang dapat membuat media pembelajaran dalam bentuk html5, android, flv dan link. Cara penggunaan yang sangat mudah dimengerti menggabungkan gambar, animasi, suara dan video dalam satu media yang dijalankan. Articulate Storyline adalah sebuah software atau perangkat lunak yang memiliki fungsi sebagai media dalam pembelajaran interaktif. Software ini dapat digunakan dalam mempresentasikan informasi sesuai dengan tujuannya. Dengan menggunakan Articulate Storyline tampilan presentasi akan jauh lebih menarik sehingga para peserta yang mengikuti presentasi tersebut akan lebih mudah untuk memahami dan terhindar dari rasa bosan (Pratama, 2018). Articulate Storyline adalah sebuah perangkat lunak yang dapat digunakan untuk membuat presentasi. Articulate Storyline memiliki fungsi yang sama dengan microsoft power point, namun articulate storyline memiliki beberapa kelebihan dibandingkan dengan microsoft power point sehingga dapat menghasilkan presentasi yang lebih menarik dan kreatif. Media pembelajaran Articulate Storyline merupakan salah satu media pembelajaran yang sengaja dibuat untuk mengemas sebuah pembelajaran (Arwanda, Irianto, \& Andriani, 2020). Aplikasi Articulate Storyline merupakan sebuah alat (software) e-learning yang berfungsi untuk membantu membangun konten (pembelajaran) yang interaktif (Darnawati, Batia, Irawaty, \& Salim, 2019). Media pembelajaran interaktif berbasis Articulate Storyline dinyatakan sangat layak digunakan untuk menunjang kegiatan proses belajar mengajar di kelas maupun sebagai belajar mandiri (Yumimi \& Rakhmawati, 2015).

Usaha dalam mengetahui kebutuhan pada saat ini, peneliti menggunakan instrumen analisis kebutuhan berupa instrumen angket. Angket merupakan sebuah pertanyaan (pernyataan) yang diberikan oleh peneliti untuk responden untuk diisi, dengan maksud minta jawaban atau pendapat responden mengenai objek-objek yang ditanyakan oleh peneliti (Arikunto, 2017).

Berlandaskan hasil dari penyebaran instrumen analisis kebutuhan berupa angket yang diberikan kepada seluruh kelas PJKR FIK UM terdapat 130 angket yang kembali. Hasil analisis 
kebutuhan dari 130 mahasiswa PJKR FIK UM yang mengambil matakuliah masase mendapatkan hasil (1) 98\% mahasiswa menyatakan bahwa mendapatkan materi terapi masase, (2) 85\% mahasiswa membutuhkan media pembelajaran baru dalam pembelajaran terapi masase, (3) 98\% mahasiswa menyatakan bahwa perlu adanya pengembangan bahan ajar pada pembelajaran terapi masase.

\section{Metode}

Berlandaskan dari latar belakang yang sudah diuraikan diatas, dengan demikian dalam penelitian ini menggunakan penelitian pengembangan. Penelitian pengembangan media belajar atau pembelajaran terapi masase ini memadankan pada jenis model penelitian pengembangan yang dikembangakan oleh Lee \& Owen dengan memakai tahapan antara lain: 1) analysis, 2) design, 3) development, 4) implementation, 5) evaluation.

Jika ditinjau dari tujuan penelitian maka jenis penelitian pengembangan ini menggunakan jenis penelitian kualitatif dan kuantitatif. Variabel yang dipakai dalam penelitian ini berupa media pembelajaran terapi masase berbasis aplikasi articulate storyline. Dalam upaya melengkapi data yang diinginkan, maka peneliti melakukan pengumpulan data dengan teknik angket. Dalam mengumpulkan data, penelitian ini menggunakan non tes.

Pada penelitian ini memakai jenis data kuantitatif dan kualitatif. Data kuantitatif dapat diperoleh dari hasil pengisian angket yang dilakukan pada analisis kebutuhan, uji coba kelompok kecil dan juga kelompok besar yang berupa angka. Sedangkan data kualitatif diperoleh dari kritik, saran, dan tanggapan dari validator.

Untuk mengumpulkan data, penelitian ini menggunakan teknik pengukuran menggunakan skala likert. Tujuan dari penggunaan skala likert yaitu untuk mengukur sikap, pendapat dan persepsi seseorang atau sekelompok orang tentang fenomena sosial (Sugiyono, 2015). Didalam instrumen skala likert ada tingkatan jawaban yang terdiri dari sangat positif dan sangat negatif. Untuk keperluan analisis data kuantitatif jawaban dapat diberi skor yang sudah ditetapkan yaitu satu (1), dua (2), tiga (3) dan empat (4).

Tabel 1. Skala Penilaian untuk Pernyataan Positif (Sugiyono, 2015)

\begin{tabular}{cccc}
\hline No. & Keterangan & Jawaban & Skor Positif \\
\hline 1. & Sangat Setuju & $\mathrm{A}$ & 4 \\
2. & Setuju & $\mathrm{B}$ & 3 \\
3. & Ragu-ragu & $\mathrm{C}$ & 2 \\
4. & Tidak Setuju & $\mathrm{D}$ & 1 \\
\hline
\end{tabular}

Rumus untuk mengolah data yang berupa analisis deskriptif kuantitatif persentase menurut sebagai berikut:

$V=\frac{\mathrm{TSEV}}{\mathrm{S}-\mathrm{max}} \times 100 \%$

Keterangan:

$\begin{array}{ll}\text { V } & \text { : Validitas } \\ \text { TSEV } & \text { : Total skor empirik validator } \\ \text { S-max } & \text { : Skor maksimal yang diharapkan } \\ 100 \% & \text { : Bilangan konstanta }\end{array}$


Dalam proses penyimpulan data dari hasil analisis persentase dapat dibedakan sesuai dengan persentase yang sudah didapat. pembedaan persentase sebagai berikut:

Tabel 2. Kriteria Kualitas Produk (Irawan \& Japarianto, 2013)

\begin{tabular}{ccc}
\hline Kriteria & Keterangan & Makna \\
\hline $75,01 \%-100,00 \%$ & Sangat Valid & Digunakan tanpa revisi \\
$50,01 \%-75,00 \%$ & Cukup Valid & Digunakan dengan revisi kecil \\
$25,01 \%-50,00 \%$ & Tidak Valid & Tidak dapat digunakan \\
$00,00 \%-25,00 \%$ & Sangat Tidak Valid & Terlarang digunakan \\
\hline
\end{tabular}

\section{Hasil dan Pembahasan}

\subsection{Hasil}

Berikut adalah data yang didapat dari hasil uji coba (kelompok kecil) pada produk pengembangan aplikasi articulate storyline dalam pembelajaran terpai masase dengan jumlah 10 mahasiswa PJKR FIK UM yang disajikan pada Tabel 3 berikut:

Tabel 3. Hasil dari Uji Coba (Kelompok Kecil)

\begin{tabular}{cccc}
\hline No. & Aspek & $\mathbf{\%}$ & Kategori \\
\hline 1 & Kejelasan & 94 & Sangat Valid \\
2 & Kesesuaian & 96 & Sangat Valid \\
3 & Kemenarikan & 94 & Sangat Valid \\
4 & Kemudahan & 94 & Sangat Valid \\
5 & Kegunaan & 99 & Sangat Valid \\
\hline Rata-Rata & & 95 & Sangat Valid \\
\hline
\end{tabular}

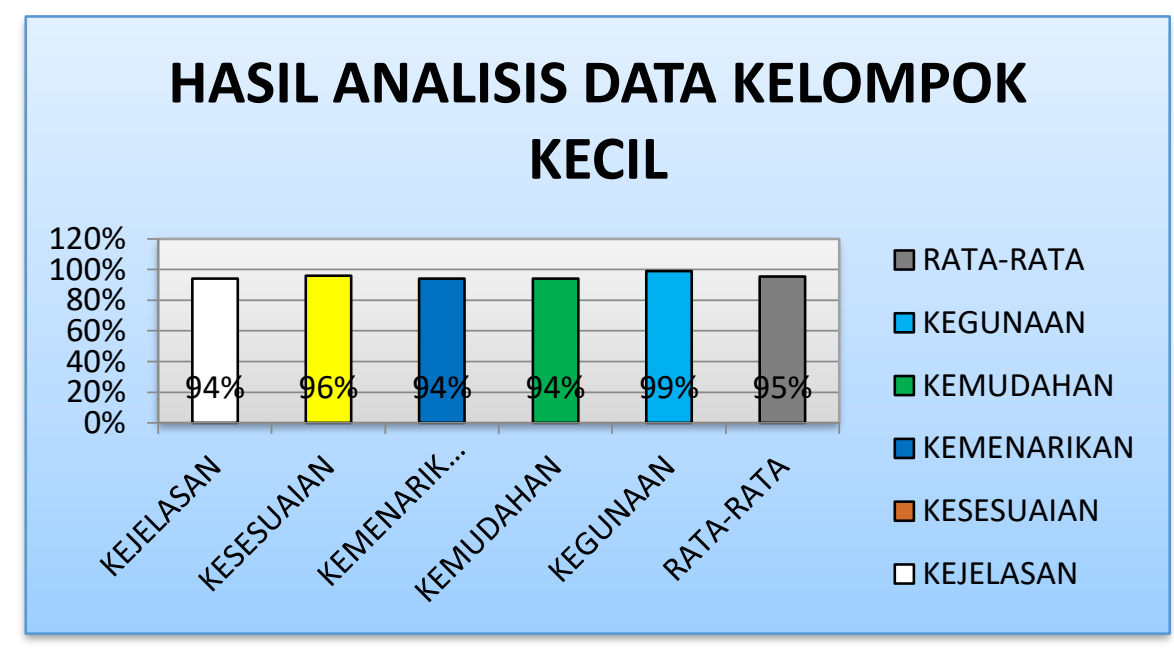

Gambar 1. Diagram Hasil Analisis Data (Kelompok Kecil)

Berlandaskan hasil dari analisis data yang didapat dari uji coba (kelompok kecil) dengan subjek sebanyak 10 mahasiswa PJKR FIK UM diperoleh hasil presentase sebesar 95\%. Hasil tersebut diperoleh berdasarkan beberapa aspek yang nantinya hasil tersebut akan dikonversikan belandaskan tabel klasifikasi kelayakan menyatakan bahwa produk 
pengembangan aplikasi articulate storyline dalam pembelajaran terapi masase dapat dikatakan layak digunakan dan termasuk dalam kriteria sangat valid.

Berikut adalah data yang didapat dari hasil uji coba (kelompok besar) pada produk pengembangan aplikasi articulate storyline dalam pembelajaran terapi masase dengan jumlah 50 mahasiswa PJKR FIK UM yang disajikan pada Tabel 4 berikut:

Tabel 4. Hasil Uji Coba (Kelompok besar)

\begin{tabular}{cccc}
\hline No. & Aspek & $\mathbf{\%}$ & Kategori \\
\hline 1 & Kejelasan & 89 & Sangat Valid \\
2 & Kesesuaian & 90 & Sangat Valid \\
3 & Kemenarikan & 89 & Sangat Valid \\
4 & Kemudahan & 91 & Sangat Valid \\
5. & Kegunaan & 93 & Sangat Valid \\
\hline Rata-Rata & 90 & Sangat Valid \\
\hline
\end{tabular}

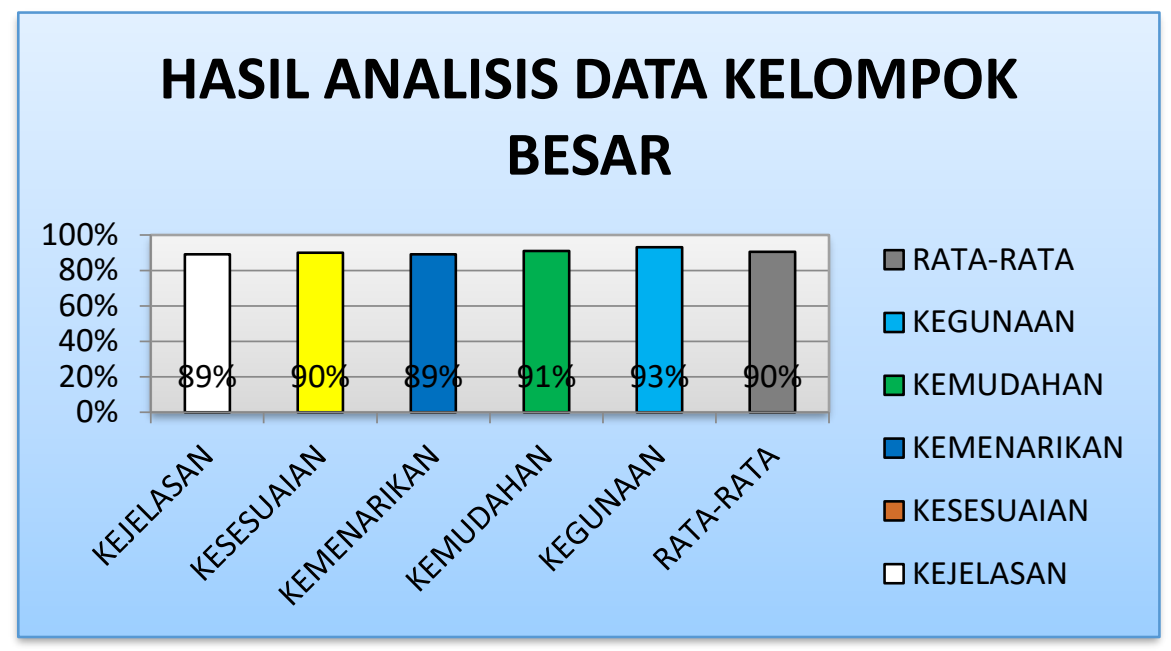

Gambar 2. Diagram Hasil Analisis Data (Kelompok Besar)

Berlandaskan hasil dari analisis data yang diperoleh dari uji coba (kelompok besar) dengan subjek sebanyak 50 mahasiswa PJKR FIK UM diperoleh hasil presentase sebesar $90 \%$. Hasil tersebut diperoleh berdasarkan beberapa aspek yang nantinya hasil tersebut dikonversikan berlandaskan tabel klasifikasi kelayakan menyatakan bahwa produk pengembangan aplikasi articulate storyline dalam pembelajaran terapi masase dapat dikatakan layak digunakan dan dapat diklasifikasikan dalam kriteria sangat valid.

\subsection{Pembahasan}

Penelitian dan pengembangan memiliki tujuan untuk mengembangkan sebuah media pembelajaran terapi masase berbasis aplikasi articulate storyline. Proses pembelajaran atau belajar mengajar merupakan upaya sistematis yang sengaja dibuat untuk menimbulkan atau menumbuhkan proses belajar dalam diri pribadi atau individu. Dalam upaya mencapai tujuan pembelajaran tentunya terdapat beberapa aspek yang menunjang pembelajaran seperti sarana prasarana, media pembelajaran dan seorang pendidik yang kompeten pada bidangnya. 
Seorang pendidik yang kompeten masih membutuhkan metode dan media pembelajaran yang cocok sehingga dalam penyampaian materi belajar dan pembelajaran akan lebih cepat dan mudah untuk dipahami atau diterima oleh murid atau peserta didik. Media belajar atau pembelajaran merupakan segala bentuk peralatan fisik yang didesain secara terencana untuk menyampaikan informasi dan membangun interaksi. Media pembelajaran ini bisa berupa kombinasi berbagai unsur media yang terdiri dari teks, grafis, foto, animasi, video dan suara yang disajikan secara interaktif dalam media pembelajaran (Darnawati et al., 2019).

Antara lain media pembelajaran yang bisa dipakai pada proses pembelajaran terapi masase adalah dengan menggunakan aplikasi articulate storyline. Articulate Storyline merupakan sebuah software atau perangkat lunak yang berfungsi sebagai media pembelajaran interaktif yang di dalamnya memuat fitur seperti text, audio serta video yang mudah digunakan. Articulate Storyline merupakan software atau perangkat lunak buatan Global Incorporation diluncurkan pada tahun 2014 yang digunakan untuk membuat pembelajaran secara e-learning yang interaktif (Nuraini \& Mintowati, 2021). Dengan menggunakan Articulate Storyline tampilan presentasi akan jauh lebih menarik sehingga para peserta yang mengikuti presentasi tersebut akan lebih mudah untuk memahami dan terhindar dari rasa bosan (Darnawati et al., 2019). Articulate storyline berguna dalam proses pembelajaran karena dapat menyampaikan materi dengan mudah. Sejalan dengan menurut Purnama, Munir, Azwar, \& Tarigan, (2019) articulate storyline memiliki tujuan tertentu dalam kegunaannya dalam hal mempresentasikan informasi (sesuai tujuan pengguna).

Dalam penelitian ini menghasilkan produk berupa pengembangan media terapi masase berbasis aplikasi articulate storyline. Produk pengembangan media pembelajaran terapi masase berbasis aplikasi articulate storyline memiliki keunggulan yaitu produk ini dapat diakses kapanpun dan dimanapun tanpa menggunakan jaringan data internet, selain itu di dalam produk pengembangan ini tersedia text, audio, serta video mengenai terapi masase. Sehingga dengan adanya produk pengembangan ini diharapkan dapat membantu dalam meningkatkan pemahaman mahasiswa PJKR FIK UM.

Produk pengembangan media pembelajaran terapi masase berbasis aplikasi articulate storyline ini juga memiliki keterbatasan, diantaranya yaitu: 1) produk pengembangan berbasis aplikasi articulate storyline ini dibatasi pada materi terapi masase, 2) Produk pengembangan berbasis aplikasi articulate storyline hanya untuk mahasiswa PJKR FIK UM.

Produk hasil pengembangan peneliti berupa media pembelajaran terapi masase berbasis aplikasi articulate storyline untuk mahasiswa PJKR FIK UM. Produk yang dikembangkan merupakan produk media sebagai sarana yang digunakan oleh dosen dalam proses pembelajaran, penyampaian materi pelajaran kepada mahasiswa yang ringkas secara menarik sehingga bisa menambah minat belajar mahasiswa. Media yang di kembangkan berbasis acrticulate storyline. Articulate storyline berguna dalam proses pembelajaran karena dapat menyampaikan materi dengan mudah. Sejalan dengan Pratama, (2018) yang menyatakan bahwa articulate storyline merupakan media yang digunakan untuk menyampaikan informasi dalam bentuk perangkat lunak. Media produk penelitian dan pengembangan digunakan sebagai sarana untuk menyampaikan sebuah informasi secara efektif dan dan efisien. Dalam rangka mendukung proses pembelajaran diperlukan media yang kreatif dan inovatif guna menarik mahasiswa dalam belajar terapi masase. 
Dalam meningkatkan suatu kemampuan maupun keterampilan peserta didik pada proses pembelajaran dibutuhkan media pembelajaran yang tepat dan sesuai. Media yang digunakan dalam proses pembelajaran berguna untuk memperjelas penyampaian informasi dan penyajian pesan. Puspitasari, Sari, Putri, \& Wuryani, (2018) media pembelajaran merupakan sarana atau alat yang digunakan dalam proses pembelajaran untuk mencapai tujuan pembelajaran yang efektif dan efisien. Yaitu dengan memanfaatkan media sebagai alat untuk menyampaikan pesan ataupun informasi yang dikemas secara menarik sehingga dapat tercapai tujuan pembelajaran. Hasil validasi ahli pembelajaran terkait dengan produk pengembangan media pembelajaran terapi masase berbasis aplikasi articulate storyline diperoleh data berupa saran evaluasi ahli pembelajaran yaitu pembenahan background, tombol, icon, dan video agar lebih menarik. Saran dan masukan telah diperbaiki oleh peneliti pada produk pengembangan berupa articulate storyline.

Produk pengembangan media articulate storyline sudah divalidasi oleh ahli media dengan tidak ada revisi atau saran. Saran dan masukan dari ahli terapi masase yaitu menambahkan keterangan di dalam video terkait teknik yang digunakan dalam terapi masase. Kegiatan pembelajaran yang menggunakan media sesuai misalnya memanfaatkan articulate storyline pada proses belajar mengajar akan menciptakan suasana yang menyenangkan dan tidak membosankan sehingga proses pembelajaran akan terfokus pada media pembelajaran yang menarik dan membuat aktivitas belajar yang efektif dan efisien. Hasil temuan lain juga menunjukan bahwa pengembangan media interaktif yang diciptakan dalam pembelajaran dapat menjadi salah satu cara menumbuhkan semangat belajar serta menjadi referensi sumber belajar tambahan (Rahman, Kurniawan, \& Heynoek, 2020).

Berdasarkan Hasil uji coba keseluruhan produk melibatkan 60 mahasiswa PJKR FIK UM. Hasil dari penelitian menunjukan produk termasuk dalam kategori sangat valid dengan hasil persentase 95\% pada uji coba kelompok kecil dengan jumlah 10 peserta kegiatan dan persentase $90 \%$ pada uji coba kelompok besar dengan jumlah 50 peserta kegiatan. Sehingga disimpulkan bahwa produk pengembangan media pembelajaran terapi masase berbasis aplikasi articulate storyline memiliki kriteria sangat valid serta layak dipakai pada kegiatan pembelajaran. Hal ini menunjukan bahwa pembelajaran menggunakan articulate storyline valid dan dapat digunakan sebagai sarana pada proses pembelajaran terapi masase. Hasil produk pengembangan media pembelajaran terapi masase menggunakan articulate storyline telah uji validasi dan uji coba serta dilakukan beberapa kali revisi sehingga memiliki beberapa kelebihan (1) Produk dibuat dengan aplikasi articulate storyline yang dapat digunakan secara offline. (2) Berisi tentang bahan ajar berupa video terapi masase yang dikemas secara menarik. (3) Produk pengembangan ini dapat digunakan oleh dosen sebagai sarana dalam proses pembelajaran online saat ini.

Diharapkan setelah dikembangkannya produk media pembelajaran terapi masase akan dapat lebih bervariasi dan lebih modern, sehingga memberikan pengaruh minat mahasiswa serta menambah pengetahuan pendidik dalam bidang teknologi yang bermanfaat untuk pengajar dalam pelaksanaan pembelajaran terapi masase.

\section{Simpulan}

Berlandaskan dari hasil analisis data yang telah dilakukan maka dapat dinyatakan bahwa produk pengembangan aplikasi articulate storyline dalam pembelajaran terapi masase dapat digunakan sebagai referensi atau sumber belajar mandiri bagi mahasiswa jurusan PJKR 
FIK UM. Dengan menggunakan produk pengembangan ini tentunya akan memudahkan para mahasiswa PJKR FIK UM dalam kegiatan pembelajaran dan mempermudah dalam memperoleh informasi, hal ini diperoleh berlandaskan dari kajian para ahli yang terdiri dari ahli terapi masase, ahli pembelajaran, dan ahli media yang dinilai berdasarkan beberapa aspek yang meliputi kesesuaian, ketepatan, kejelasan, kemudahan, dan kemenarikan. Selain itu juga dapat dilihat melalui hasil analisis data yang didapat dari analisis kebutuhan, uji coba kelompok kecil, dan uji coba kelompok besar.

\section{Daftar Rujukan}

Arikunto, S. (2017). Pengembangan Instrumen Penelitian dan Penilaian Progam. Yogyakarta: Pustaka Pelajar.

Arwanda, P., Irianto, S., \& Andriani, A. (2020). Pengembangan Media Pembelajaran Articulate Storyline Kurikulum 2013 Berbasis Kompetensi Peserta Didik Abad 21 Tema 7 Kelas Iv Sekolah Dasar. AlMadrasah: Jurnal Pendidikan Madrasah Ibtidaiyah, 4(2), 193. https://doi.org/10.35931/am.v4i2.331

Asmadawati. (2014). Perencanaan Pengajaran. Darul Ilmi, 02(01), 1-13.

Bervoets, D. C., Luijsterburg, P. A. J., Alessie, J. J. N., Buijs, M. J., \& Verhagen, A. P. (2015). Massage therapy has short-term benefits for people with common musculoskeletal disorders compared to no treatment: A systematic review. Journal of Physiotherapy, 61(3), 106-116. https://doi.org/10.1016/j.jphys.2015.05.018

Darnawati, Batia, L., Irawaty, \& Salim. (2019). Pemberdayaan Guru Melalui Pengembangan Multimedia Pembelajaran Interaktif Dengan Aplikasi Articulate Storyline. Jurnal Pengabdian Kepada Masyarakat, $1(1)$.

Dwijayani, N. M. (2019). Development of circle learning media to improve student learning outcomes. Journal of Physics: Conference Series, 1321(2), 171-187. https://doi.org/10.1088/1742-6596/1321/2/022099

Harsanti, S., \& Graha, A. S. (2014). Efektifitas Terapi Masase dan Terapi Latihan Pembebanan Dalam Meningkatkan Range of Movement Pasca Cedera Ankle Ringan. JOURNAL MEDIKORA Vol. XIII No. 1 Oktober 2014 EFEKTIFITAS, XIII(1).

Irawan, D., \& Japarianto, E. (2013). Analisa Pengaruh Kualitas Produk Terhadap Loyalitas Melalui Kepuasan Sebagai Variabel Intervening Pada Pelanggan Restoran Por Kee Surabaya. Jurnal Manajemen Pemasaran.

Kurniawan, A. W. (2019). Multimedia-Based Learning Model for Gymnastics Skills. 7(Icssh 2018), 33-36. https://doi.org/10.2991/icssh-18.2019.8

Mukhlis, N. A., Kurniawan, A. W., \& Kurniawan, R. (2020). Pengembangan Media Kebugaran Jasmani Unsur Kekuatan Berbasis Multimedia Interaktif. Sport Science and Health, 2(11), 566-581.

Nuraini, D. V., \& Mintowati. (2021). Pengembangan Multimedia Interaktif Berbasis Articulate Storyline Untuk Pembelajaran Menulis Puisi Siswa Kelas X Sman 3 Ponorogo. 8(1), 1-9.

Nurpitasari, E., Aji, B. S., \& Kurniawan, S. J. (2018). Pengembangan Kompetensi Teknologi Dan Peran Konselor Dalam Menghadapi Peserta Didik Di Era Disrupsi. 10-14.

Pratama, R. A. (2018). Media Pembelajaran Berbasis Articulate Storyline 2 Pada Materi Menggambar Grafik Fungsi Di Smp Patra Dharma 2 Balikpapan Learning Media Based On Articulate Storyline 2 On Drawing Function Graphs Lesson In Smp Patra Dharma 2 Balikpapan Pendahuluan Matemati. 7(1), 19-35.

Purnama, D. A., Munir, M., Azwar, E., \& Tarigan, M. R. M. (2019). Pengaruh Model Active Debate Terhadap Hasil Belajar Siswa Pada Materi Ekosistem Di Kelas X Madrasah Aliyah Swasta Proyek Univa Medan. Jurnal Biolokus, 2(1), 5. Retrieved from https://media.neliti.com/media/publications/292801-studi-metaanalisis-pengaruh-video-pembe-7bf17271.pdf

Puspitasari, P., Sari, P., Putri, J., \& Wuryani, W. (2018). Pengaruh Penggunaan Media Pembelajaran terhadap Motivasi Belajar Mahasiswa IKIP Siliwangi. Parole: Jurnal Pendidikan Bahasa Dan Sastra Indonesia, 1(2), 227-232.

Rahman, Z., Kurniawan, A. W., \& Heynoek, F. P. (2020). Pengembangan Pembelajaran Kebugaran Jasmani Unsur Kecepatan Berbasis Multimedia Interaktif. Sport Science and Health, 2(1), 78-92. Retrieved from http://journal2.um.ac.id/index.php/jfik/article/view/11692/5123

Sugiyono. (2015). Metode Penelitian Pendidikan. Bandung: Alfabeta. 
Sport Science and Health, 3(7), 2021, 533-542

Tjandrawinata, R. R., \& Medica, D. (2016). Industri 4 . 0 : revolusi industri abad ini dan pengaruhnya pada bidang kesehatan dan bioteknologi. (April). https://doi.org/10.5281/zenodo.49404

Toenlioe, A. J. (2017). Pengembangan Kurikulum Teori, Catatan Kritis, dan Panduan. Bandung: PT Refika Aditama.

Wena, M. (2013). Strategi Pembelajaran Inovatif Kontemporer (ke 8). Jakarta: PT Bumi Aksara.

Yumimi, S., \& Rakhmawati, L. (2015). Pengembangan Media Pembelajaran Interaktif Berbasis Articulate Storyline Pada Mata Diklat Teknik Elektronika Dasar Di Smk Negeri 1 Jetis Mojokerto. Jurnal Pendidikan Teknik Elektro, 4(3), 845-849. 